\title{
不思議現象に対する態度尺度（APPle）短縮版の作成 (2)
}

\author{
不思議現象に対する態度 (30)

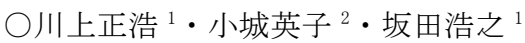 \\ $\left({ }^{1}\right.$ 大阪樟蔭女子大学心理学部・2 聖心女子大学文学部) \\ キーワード : 不思議現象, 尺度, 短縮版
}

Constructing attitudes towards paranormal phenomena scale (APPle) short edition (2): Attitudes towards Paranormal Phenomena (30) Masahiro KAWAKAMI ${ }^{1}$, Eiko KOSHIRO ${ }^{2}$, and Hiroyuki SAKATA ${ }^{1}$,

( ${ }^{1}$ Faculty of Psychology, Osaka Shoin Women's Univ., ${ }^{2}$ Faculty of Liberal Arts, Univ. of the Sacred Heart)

Key Words: paranormal phenomena, scale, short edition

\section{目 的}

坂田・川上・小城（印刷中，日本心理学会大会発表論文集） は，不思議現象に対する態度尺度 APPle（Attitude toward Paranormal Phenomena Scale ; 小城・坂田・川上，2008）の短 縮版，APPle SE/30 を提唱した。APPle（SE/30）は，不思議 現象に対する態度を，占い・呪術嗜好性，スピリチュアリテ イ信奉, 娛楽的享受, 懐疑, 恐怖, 霊体験の 6 つの下位尺度 によって測定するものである。本研究では, 坂田他 (印刷中) とは別のデータ（小城他，2008）を用い，APPle SE/30 の妥当 性を検討することを目的とする。

\section{方 法}

調査対象者 大阪府の $\mathrm{O}$ 大学, $\mathrm{K}$ 大学および $\mathrm{S}$ 大学, 愛知県 の $\mathrm{N}$ 大学, $\mathrm{G}$ 大学, 東京都の $\mathrm{K}$ 大学, 埼玉県の $\mathrm{B}$ 大学, 広島 県の F 大学に所属する大学生 699 名（男性 339 名, 女性 356 名, 性別不明 4 名, 平均年齢 19.7 歳 : $S D=1.8$ )

質問紙の構成 APPle オリジナルの 55 項目, LOC 尺度 18 項 目（鎌原・樋口・清水，1982）, 認知欲求尺度 15 項目（神山・ 藤原，1991）, 自己認識欲求尺度 14 項目・ネガティブ情報回 避欲求尺度 7 項目（いずれも上瀬，1992）, 賞賛獲得欲求尺度 5 項目・拒否回避欲求尺度 4 項目（いずれも菅原, 1986）, 死 の恐怖尺度 7 項目（河合・下仲・中里, 1996）, Big Five ダイ ジェスト版 30 項目（松井，2001）。

手続き 調査対象者は授業中に集団でこれに回答することを 求められ，各自のペースで回答を行った。

\section{結果と考察}

小城他（2008）と同様に，APPle SE/30 の下位尺度と性格特 性の Big Five ダイジェスト版およびその他の個人的欲求との 相関係数を算出した。Table 1 に示したように，その相関は， APPle オリジナル版の下位尺度において認められた相関と概 ね類似しており, APPle SE/30 が概ね妥当な短縮版であること
を示した。また, 下位尺度ごとの男女差を検討した結果 (Table 2) も, オリジナル版と短縮版とで整合的であり,さらに川上・ 小城・坂田（2006, 社会心理学会大会発表論文集）とも整合的 であった。

川上・小城・坂田（2006, 日本心理学会大会発表論文集） は調査対象者を LOC の得点によって Low, Middle, High.の 3 群に分割して APPle の下位尺度得点を比較し, 中程度の LOC が，占いや呪術への嗜好性を高める可能性を示唆した。 同様の分析を APPle SE/30 の下位尺度得点に対しても行った ところ，占い。呪術嗜好性を従属変数とした場合のみ LOC の 効果が有意となり $(F(2,676)=4.38, p<.05)$, Middle 群で High 群より, 占い.呪術嗜好性得点が高いことが示された。この結 果も川上他（2006）の結果と整合的であり，APPle SE/30 が短 縮版として妥当であることを示している。

以上のことから，30 項目からなる APPle SE/30 は, APPle の概ね妥当な短縮版であると結論づけることができる。

\section{引用文献}

小城英子・坂田浩之・川上正浩 (2008). 不思議現象に対す る態度; 態度構造の分析および類型化 社会心理学研究,

23, 246-258.

Table 2 男女別下位尺得点平均値 $(S D)$ と $\mathrm{t}$ 検定 $(* * p<.01 * p<.05)$

\begin{tabular}{|c|c|c|c|c|c|c|c|c|c|c|c|}
\hline & \multicolumn{6}{|c|}{ 短縮版 } & \multicolumn{5}{|c|}{ オリジナル版 } \\
\hline & & 男性 & & 女性 & $\mathrm{t}$ & & & 男性 & & 女性 & $\mathrm{t}$ \\
\hline $\begin{array}{l}\text { 占い・呪術 } \\
\text { 嗜好性 }\end{array}$ & 2.58 & $(0.94)$ & 2.84 & $(0.83)$ & 3.87 & ** & 2.59 & $(0.81)$ & 2.90 & $(0.71)$ & $5.14^{* *}$ \\
\hline $\begin{array}{l}\text { スピリチュ } \\
\text { アリティ信奉 }\end{array}$ & 3.24 & $(1.10)$ & 3.63 & $(0.84)$ & 5.27 & ** & 3.27 & $(0.94)$ & 3.63 & $(0.72)$ & 5.56 ** \\
\hline 娛楽的享受 & 3.08 & (1.04) & 2.98 & $(0.92)$ & 1.33 & & 3.18 & $(0.96)$ & 3.10 & $(0.82)$ & 1.23 \\
\hline 懐疑 & 2.90 & $(0.91)$ & 2.73 & $(0.78)$ & 2.57 & * & 2.90 & $(0.91)$ & 2.73 & $(0.78)$ & $2.57 *$ \\
\hline 恐怖 & 2.09 & ( 0.84 ) & 2.31 & $(0.80)$ & 3.45 & $* *$ & 2.02 & ( 0.82$)$ & 2.25 & $(0.78)$ & $3.79^{* *}$ \\
\hline 霊体験 & 1.63 & $(0.82)$ & 1.55 & $(0.70)$ & 1.44 & & 1.83 & $(0.84)$ & 1.75 & $(0.73)$ & 1.32 \\
\hline
\end{tabular}

Table 1 APPle短縮版およびオリジナル版下位尺度と個人特性との相関係数 $(* * p<.01 * p<.05)$

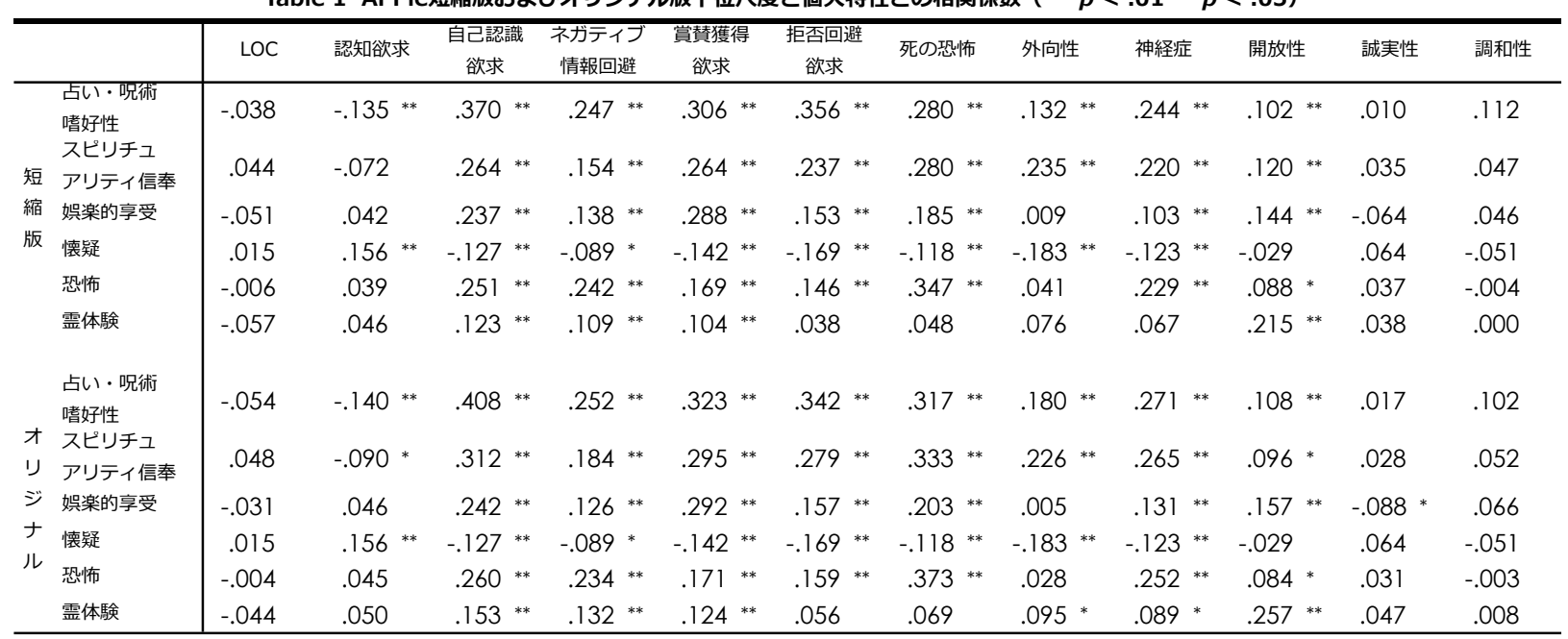

